\title{
Studi Kritis Mengenai Kewenangan Dewan Kehormatan Penyelenggara Pemilu dalam Mengawal Electoral Integrity di Indonesia
}

\author{
M. Imam Nasef \\ Mahasiswa Magister Hukum Kenegaraan Universitas Indonesia \\ Jl. Salemba Raya No.6 Jakarta Pusat 10430 \\ imamnasef@gmail.com
}

\begin{abstract}
Honorary Council Election (DKPP) is considered very progressive because in less than two years from its inauguration, it has solved around 127 cases. However, there are several decisions made by DKPP which are controversial because they make decisions and give sanctions to not only violations of ethical codes, but also administrative sectors and conflicts related to general elections. The problems of this research are: first, what are the limits of DKPP's authority in investigating and making decisions on ethical code violation during general election? Second, how is the relationship pattern among KPU (Election Supervisory Committee), Bawaslu (Election Watchdog), and DKPP which is based on electoral integrity in conducting general election? This research employed statute and conceptual approach as well as qualitative analysis. The findings show that: first, the limits of DKPP's authority have been governed in the Constitution of Elections. DKPP only has authority to investigate and make decisions on the notions of ethical code violations which are done by election committee. Second, the pattern of the relationship among election committees in Indonesia has actually adopted the electoral integrity principles, but it will be better if DKPP, in doing its duties, does not overlap with the authority of other agencies or institutions so that they can work professionally.
\end{abstract}

Keywords: Authority, DKPP, electoral integrity

\begin{abstract}
Abstrak
Dewan Kehormatan Penyelenggara Pemilu (DKPP) dipandang sangat progresif, terbukti dalam waktu kurang dari dua tahun sejak dilantik, telah berhasil menyelesaikan kurang lebih 217 perkara. Namun, terdapat beberapa putusan DKPP yang kontroversial, karena tidak hanya memutuskan dan memberikan sanksi terhadap pelanggaran kode etik, tetapi seringkali masuk ke ranah administrasi dan sengketa pemilu. Permasalahan dalam penelitian ini pertama, apakah batasan kewenangan DKPP dalam memeriksa dan memutus dugaan pelanggaran kode etik penyelenggara pemilu? Kedua, bagaimana pola hubungan antara KPU, Bawaslu, dan DKPP berbasis electoral integrity dalam penyelenggaraan pemilu? Metode penelitian yang digunakan statute and conceptual approach serta analisis kualitatif. Penelitian ini menyimpulkan, pertama, batasan kewenangan DKPP telah diatur dalam UU Penyelenggara Pemilu. DKPP hanya berwenang memeriksa dan memutus dugaan pelanggaran kode etik yang dilakukan oleh penyelenggara pemilu. Kedua, pola hubungan antar penyelenggara pemilu di Indonesia sebenarnya telah mengadopsi prinsip electoral integrity, namun terdapat catatan khusus bagi DKPP, yaitu akan lebih baik apabila dalam menjalankan wewenangnya tidak sampai overlapping dengan wewenang lembaga lain, sehingga dapat bekerja secara profesional.
\end{abstract}

Key Word: Kewenangan, DKPP, electoral integrity 


\section{Pendahuluan}

Sistem demokrasi modern menghendaki pemilu tidak hanya diselenggarakan sebagai ritual suksesi kepemimpinan semata. Lebih dari itu, pemilu diharapkan benar-benar menjadi aktualisasi dan manifestasi kedaulatan rakyat. ${ }^{1}$ Dalam rangka menjunjung tinggi kedaulatan rakyat tersebut, penyelenggaraan pemilu harus didasarkan pada prinsip free and fair election (bebas dan adil). Prinsip free and fair election telah menjadi pedoman negara-negara demokrasi modern dalam penyelenggaraan pemilu beberapa dekade terakhir. ${ }^{2}$

Dalam diskursus kepemiluan pada skala global, perhatian dunia internasional dalam beberapa tahun terakhir tidak lagi hanya terfokus pada perwujudan free and fair election, tetapi mulai mengkampanyekan pentingnya integritas pemilu (electoral integrity). ${ }^{3}$ Indonesia sebagai salah satu negara pada gelombang demokratisasi ketiga tidak hanya sedang megembangkan konsep pemilu berintegritas. Lebih jauh dari hal tersebut, Indonesia telah mewujudkannya dalam penyelenggaraan pemilu.

Dalam rangka mewujudkan penyelenggara pemilu ${ }^{4}$ yang mematuhi nilainilai moral dan etika sebagai manifestasi electoral integrity, di Indonesia dibentuk suatu Dewan Kehormatan Penyelenggara Pemilu (selanjutnya disebut DKPP) yang bersifat permanen melalui Undang-Undang Nomor 15 Tahun 2011 tentang Penyelenggara Pemilihan Umum (selanjutnya disebut UU Penyelenggara Pemilu). Kelahiran DKPP ini merupakan salah satu bukti Indonesia telah menerapkan electoral integrity.

1 Wujud kedaulatan rakyat dapat diimplementasikan dalam pemilu melalui partisipasi langsung rakyat dalam menentukan pemimpinnya. Gagasan partisipasi rakyat adalah rakyat berhak turut menentukan siapa-siapa yang akan menjadi pemimpin yang nantinya menentukan kebijaksanaan umum (public policy). Lihat Abdul Bari Azed dan Makmur Amir, Pemilu dan Partai Politik di Indonesia, PS-HTN FH UI, Jakarta, 2005, hlm. 20.

${ }^{2}$ Guy S. Goodwin-Gill, Free and Fair Elections: International Law and Practice, Inter-Parliamentary Union, Geneva, 1994, hlm. 8.

3 Juli 2012 Asosiasi Politik Internasional bertempat di Madrid mengadakan kongres dunia tentang "Prospek dan Tantangan Integritas Pemilu". September 2012 Global Commision on Election, Democracy and Security yang diketuai oleh Kofi A. Annan mempublikasikan sebuah laporan kerja tentang "Strategi Meningkatkan Integritas Pemilu di Seluruh Dunia". Terakhir, Harvard University pada bulan Juni 2013 yang lalu juga mengadakan workshop bertemakan "Concepts and Indices of Electoral Integrity".

${ }^{4}$ Penyelenggara pemilu menurut Pasal 23E UUD 1945 adalah "komisi pemilihan umum" (dengan huruf kecil), tetapi oleh undang-undang dijabarkan menjadi terbagi ke dalam 2 (dua) kelembagaan yang terpisah dan masing-masing bersifat independen, yaitu "Komisi Pemilihan Umum" (dengan huruf Besar) atau KPU, dan "Badan Pengawas Pemilihan Umum" atau BAWASLU (Bawaslu). Lihat Jimly Asshiddiqie, Pengenalan tentang DKPP untuk Penegak. Hukum, Makalah, disampaikan dalam Forum Rapat Pimpinan Kepolisian Republik Indonesia di Jakarta pada Februari 2013, hlm. 1. 
Berdasarkan Pasal 109 ayat (2) UU Penyelenggara Pemilu, DKPP diberi wewenang untuk memeriksa dan memutuskan pengaduan dan/atau laporan adanya dugaan pelanggaran kode etik yang dilakukan oleh penyelenggara pemilu. ${ }^{5}$ Selanjutnya dalam Pasal 3 ayat (2) Peraturan DKPP Nomor 1 Tahun 2013 tentang Pedoman Beracara Kode Etik Penyelenggara Pemilihan Umum (Selanjutnya disebut Peraturan Beracara Kode Etik DKPP) dinyatakan bahwa penegakan kode etik dilaksanakan oleh DKPP.

DKPP dapat dikatakan sangat progresif dalam melaksanakan tugas dan wewenangnya. Terbukti hanya dalam kurun waktu kurang dari dua tahun sejak dilantik Presiden pada tanggal 12 Juni 2012, DKPP telah menerima laporan kurang lebih 217 perkara pelanggaran kode etik penyelenggara pemilu. Sebanyak kurang lebih 81 perkara telah diproses dan disidangkan oleh DKPP.6 Prestasi tersebut bukan tanpa kritik, berbagai kalangan menilai berbagai putusan DKPP terkait perkara pelanggaran kode etik penyelenggara pemilu bermasalah.

Setidaknya terdapat 3 (tiga) putusan DKPP yang kontroversial. Di antaranya: 1) Putusan DKPP Nomor 73/DKPP-PKE-II/2013 tentang perkara pelanggaran kode etik Badan Pengawas Pemilu Republik Indonesia (selanjutnya disebut Baswalu RI); 2) Putusan DKPP Nomor 74/DKPP-PKE-II/2013 tentang perkara pelanggaran kode etik KPU Provinsi Jawa Timur; dan 3) Putusan DKPP Nomor 83 \& 84/DKPP-PKE-II/2013 tentang perkara pelanggaran kode etik Komisi Pemilihan Umum (selanjutnya disebut KPU) Kota Tangerang.

Dalam ketiga putusan tersebut, DKPP tidak hanya memutus bersalah dan memberikan sanksi terhadap penyelenggara pemilu yang terbukti melakukan pelanggaran kode etik, tetapi DKPP juga memerintahkan KPU untuk memulihkan hak-hak pengadu yang sebenarnya telah masuk ranah administrasi pemilu. Dalam putusan Nomor 73/DKPP-PKE-II/2013 misalnya, DKPP secara implisit memerintahkan KPU untuk memasukkan kembali Selviana Sofyan Hosen

5 Penyelenggara pemilu yang dimaksud adalah anggota KPU, anggota KPU Provinsi, anggota KPU Kabupaten/Kota, anggota PPK, anggota PPS, anggota PPLN, anggota KPPS, anggota KPPSLN, anggota Bawaslu, anggota Bawaslu Provinsi dan anggota Panwaslu Kabupaten/Kota, anggota Panwaslu Kecamatan, anggota Pengawas Pemilu Lapangan dan anggota Pengawas Pemilu Luar Negeri. Lihat selengkapnya dalam Pasal 109 ayat (2) Undang-Undang Nomor 15 Tahun 2011 tentang Penyelenggara Pemilihan Umum. 86.

6 Jimly Asshiddiqie, Menegakean Etika Penyeleggara Pemilu, PT. Raja Grafindo Persada, Jakarta, 2013, hlm. 
(pengadu) ke dalam Daftar Calon Tetap (selanjutnya disebut DCT). ${ }^{7}$ Begitu juga dengan putusan Nomor 74/DKPP-PKE-II/213, selain menjatuhkan sanksi peringatan atas Ketua KPU Jawa Timur Andry Dewanto Ahmad dan pemberhentian sementara atas Komisioner KPU Jawa Timur lainnya, DKPP juga memerintahkan KPU untuk melakukan peninjauan kembali secara cepat dan tepat terhadap prinsip dan etika dalam perlindungan hak konstitusional Khofifah Indar Parawansa sebagai calon peserta Pemilukada Jawa Timur. ${ }^{8}$

Sebagaimana dalam dua putusan sebelumnya, dalam putusan Nomor 83 \& 84/DKPP-PKE-II/2013, selain menjatuhkan sanksi berupa pemberhentian sementara terhadap KPU Kota Tangerang karena terbukti melakukan pelanggaran kode etik, DKPP juga memerintahkan kepada KPU Provinsi Banten untuk memulihkan dan mengembalikan hak konstitusional bakal pasangan calon Arief R. Wismansyah-Sachrudin dan bakal pasangan calon Ahmad Marju KodriGatot Suprijanto untuk menjadi pasangan calon peserta Pemilukada Walikota dan Wakil Walikota Tangerang tahun 2013.9 Ketiga putusan tersebut menunjukkan DKPP telah masuk ke ranah administrasi pemilu dan sengketa pemilu.

Administrasi pemilu merupakan ranah kewenangan KPU sebagaimana dinyatakan dalam Pasal 8 UU Penyelenggara Pemilu. Mengenai dugaan pelanggaran administrasi pemilu yang meliputi tata cara, prosedur dan mekanisme pemilu dapat dilaporkan kepada Bawaslu sebagaimana diatur dalam Pasal 73 ayat (4) UU Penyelenggara Pemilu. Sementara itu, untuk penyelesaian sengketa pemilu baik antar peserta pemilu maupun peserta pemilu dengan penyelenggara pemilu sebagai akibat dikeluarkannya keputusan KPU, KPU Provinsi, dan KPU Kabupaten/Kota merupakan wewenang Bawaslu sebagaimana diatur dalam Pasal 258 ayat (1) Undang-Undang Nomor 8 Tahun 2012 tentang Pemilihan Umum Anggota Dewan Perwakilan Rakyat, Dewan Perwakilan Daerah, dan Dewan Perwakilan Rakyat Daerah (selanjutnya disebut UU Pemilu Legislatif).

Apabila dikaitkan dengan konstruksi pengaturan dalam peraturan perundang-undangan di atas, tindakan yang dilakukan DKPP melalui ketiga

${ }^{7}$ Lihat Putusan DKPP Nomor 73/DKPP-PKE-II/2013.

${ }^{8}$ Lihat Putusan DKPP Nomor 74/DKPP-PKE-II/2013.

${ }^{9}$ Lihat Putusan DKPP Nomor 83 \& 84/DKPP-PKE-II/2013. 
putusannya dapat menimbulkan persoalan hukum karena telah mengaburkan batas-batas wewenang dan pola hubungan antar penyelenggara pemilu itu sendiri. Dalam menjalankan tugas dan wewenangnya, DKPP sudah seharusnya mengacu pada peraturan perundang-undangan yang berlaku. Harus diakui, UU Penyelenggara Pemilu sendiri memang tidak secara komprehensif mengatur tugas dan wewenang DKPP, sehingga DKPP yang terkesan sangat "akrobatik" dalam menjalankannya tidak dapat dipersalahkan seutuhnya. Namun, apabila tidak dievaluasi, tindakan yang dilakukan DKPP akan menjadi trend dan tidak menutup kemungkinan menjadi yurisprudensi yang akan selalu diikuti dalam putusan-putusan selanjutnya.

\section{Rumusan Masalah}

Berdasarkan uraian di atas, dirumuskan permasalahan sebagai berikut: pertama, apakah batasan kewenangan DKPP dalam memeriksa dan memutus dugaan pelanggaran kode etik penyelenggara pemilu? Kedua, bagaimana pola hubungan antara KPU, Bawaslu, dan DKPP berbasis electoral integrity dalam penyelenggaraan pemilu?

\section{Tujuan Penelitian}

Berdasarkan uraian permasalahan tersebut, tulisan ini difokuskan untuk mengkaji lebih lanjut mengenai dua hal, yaitu: pertama, batasan kewenangan DKPP dalam memeriksa dan memutus dugaan pelanggaran kode etik penyelenggara pemilu. Melalui studi kasus atas 3 (tiga) putusan DKPP yaitu: Putusan Nomor 73/DKPP-PKE-II/2013, Nomor 74/DKPP-PKE-II/2013, dan Nomor 83 \& 84/DKPP-PKE-II/2013, tulisan ini akan menganalisis secara kritis sepak terjang DKPP dalam melaksanakan wewenangnya. Kedua, pola hubungan antara KPU, Bawaslu, dan DKPP berbasis electoral integrity dalam penyelenggaraan pemilu. Tulisan ini akan menganalisis pola hubungan antara penyelenggara pemilu yang didasari pada indikator-indikator pemilu berintegritas. 


\section{Metode Penelitian}

Penelitian ini termasuk dalam kategori penelitian hukum normatif karena hanya menggunakan bahan kepustakaan atau data sekunder yang terdiri dari: 1) bahan hukum primer yang terdiri dari: a) Undang-Undang Dasar Negara Republik Indonesia Tahun 1945; b) Undang-Undang Nomor 15 Tahun 2011 tentang Penyelenggara Pemilihan Umum; c) Undang-Undang Nomor 8 Tahun 2012 tentang Pemilihan Umum Anggota Dewan Perwakilan Rakyat, Dewan Perwakilan Daerah, dan Dewan Perwakilan Rakyat Daerah; d)Peraturan perundang-undangan lainnya yang berkaitan dengan penelitian ini; e) Putusan DKPP Nomor 73/DKPP-PKE-II/2013, Nomor 83 \& 84/DKPP-PKE-II/2013, dan Nomor 74/DKPP-PKE-II/2013. 2) Bahan hukum sekunder, yang terdiri dari buku-buku literatur, hasil penelitian dan karya ilmiah lainnya yang berhubungan dengan topik penelitian ini. Selain itu, terdapat juga dokumen hasil wawancara dengan pakar-pakar hukum dan politik. 3) Bahan hukum tersier, yang terdiri dari: a. Kamus Umum Bahasa Indonesia; b. Kamus Inggris - Indonesia; c. Kamus Istilah Hukum; d. Ensiklopedia.

Metode pendekatan yang digunakan dalam penelitian ini adalah: pertama, pendekatan peraturan perundang-undangan (statue approach), penelitian ini akan menganalisis fokus kajian penelitian dari sudut pandang atau menurut ketentuan hukum/perundang-undangan yang berlaku. Kedua, pendekatan konseptual (conceptual approach), penelitian ini akan menganalisis fokus kajian penelitian beranjak dari pandangan-pandangan dan doktrin-doktrin yang berkembang di dalam ilmu hukum khususnya ilmu hukum tata negara dan hukum administrasi negara. Berangkat dari pemahaman terhadap teori, asas, doktrin diharapkan dapat membantu pemecahan masalah hukum yang dikaji dalam penelitian ini.

Adapun metode analisis data yang digunakan adalah analisis kualitatif. Data yang diperoleh dalam penelitian ini akan disajikan dan diolah secara kualitatif dengan langkah-langkah sebagai berikut: (1) data yang diperoleh dari penelitian diklasifikasikan sesuai dengan permasalahan dalam penelitian; (2) hasil klasifikasi data selanjutnya disistematisasikan; dan (3) data yang telah 
disistematisasikan kemudian dianalisis untuk dijadikan dasar dalam pengambilan kesimpulan.

\section{Hasil Penelitian dan Pembahasan}

\section{Tinjauan Konseptual Mengenai Electoral Integrity}

Dalam "the Advantage of Integrity", Adrian Gostick dan Dana Telford, peneliti dari Harvard University mendefinisikan integritas sebagai ketaatan yang kuat pada sebuah kode, khususnya nilai moral atau nilai artistik tertentu. ${ }^{10}$ Definisi yang tidak jauh berbeda juga dikemukakan oleh tim yang tergabung dalam Global Commision on Election, Democracy and Security yang diketuai Kofi A. Annan. Integritas sebagaimana dielaborasi dalam laporan kerja tim yang diberi judul "Deepening Democracy: A Strategy for Improving the Integrity of Election Worldwide" tersebut, merujuk pada kepatuhan yang kukuh pada nilai moral dan etika. ${ }^{11}$ Dengan demikian, penyelenggaraan pemilu yang berintegritas menghendaki seluruh elemen yang terlibat di dalamnya baik penyelenggara maupun peserta tunduk dan patuh pada nilai-nilai moral dan etika kepemiluan.

Dalam filfasat moral, etika merupakan bagian penting dalam persoalan moral setiap orang, sehingga ia menjadi batas-batas nilai yang membedakan perbuatan baik buruk manusia dengan makhluk lain. Sigmund Freud mengatakan di dalam kehidupan jiwa manusia terdapat "das es" dan "das ich". Das es merupakan ketidaksadaran manusia dalam kekuatan-kekuatan hidup dan das ich bagian dari kesadaran individu untuk memaksimalkan potensi kemanusiaannya untuk memahami keadaan yang baik bersifat internal atau dalam dirinya maupun keadaan-keadaan yang muncul disebabkan oleh kekuatan eksternal sebagai pengendali apa yang disebut das es. Dalam perspektif ini, manusia sesungguhnya memiliki dua potensi besar yang menjadi unsur

10 Adrian Gostick dan Dana Telford, Keunggulan Integritas, Terj, PT Bhuana Ilmu Populer, Jakarta, 2006, hlm. 13-14.

11 Global Commision on Election, Democracy and Security, Deepening Democracy: A Strategy for Improving the Integrity of Elections Worldwide, Kofi Annan Foundation in Cooperation with International Institute for Democracy and Electoral Assistance (IDEA), Geneva, 2012, hlm. 14. 
kecenderungan bertindak yakni potensi untuk bertindak destruktif dan konstruktif. ${ }^{12}$

Pentingnya mewujudkan pemilu berintegritas (electoral integrity) didasari pada pandangan bahwa pemilu diselenggarakan untuk menjunjung tinggi sekaligus menegakkan hak asasi manusia dan prinsip demokrasi. Apabila pemilu tidak dilaksanakan dengan basis integritas, maka berpotensi melahirkan penyelenggara pemilu yang tidak bertanggungjawab yang berimplikasi pada minimnya partisipasi politik dan hilangnya kepercayaan publik pada proses demokrasi. ${ }^{13}$ Ketika mimpi buruk apatisme publik terhadap proses demokrasi terjadi, penghormatan, perlindungan dan penegakan hak asasi manusia akan terabaikan.

Senada dengan pandangan di atas, Jimly Asshiddiqie mengatakan dalam konteks penyelenggaraan pemilu, integritas anggota penyelenggara pemilu menjadi modal utama dalam mewujudkan pemilu yang demokratis. Pemilu merupakan sarana utama dalam menjalankan kedaulatan rakyat, sehingga tugas dan fungsi penting penyelenggara pemilu salah satunya memetakan program tahapan-tahapan pemilu agar dapat berjalan dengan baik. Untuk dapat melaksanakan tugas dan fungsinya dengan baik, diperlukan benteng yang kokoh dalam diri setiap anggota penyelenggara pemilu yaitu integritas. ${ }^{14}$

Kofi A. Annan dan tim Global Commision on Election, Democracy and Security mengajukan 3 (tiga) indikator pemilu berintegritas. Pertama, pemilu diselenggarakan berdasarkan prinsip demokrasi dengan hak pilih yang berlaku umum/universal dan kesetaraan politik seperti digambarkan dalam Deklarasi Umum HAM dan Perjanjian Internasional tentang Hak-hak Sipil dan Politik. Kedua, persiapan dan pelaksanaan pemilu dilakukan secara profesional, imparsial, dan transparan. Ketiga, kepatutan dan praktik etika menuntun seluruh siklus pemilu (electoral circle). ${ }^{15}$

12 Jimly Asshiddiqie, "Dewan Kehormatan Penyelenggara Pemilu: Mengawal Kehormatan Pemilu”, makalah yang disampaikan dalam kegiatan Sosialisasi Dewan Kehormatan Penyelenggara Pemilihan Umum Republik Indonesia dengan jajaran Pemerintahan Provinsi Aceh, LSM, Ormas, OKP, Parpol, Media Massa dan Akademisi, di Aula Kantor Gubernur Aceh pada Jumat 21 Juni 2013 dan Sabtu 22 Juni 2013 di Ballrom Rektorat UNSIYAH Aceh, hlm. 1-2.

${ }_{13}$ Global Commision on Election, Democracy and Security, 2012, Deepening Democracy ... Op., Cit., hlm. 15-16.

14 Jimly Asshiddiqie, Menegakkan Etika ... Op.Cit., hlm. 68.

15 Global Commision on Election, Democracy and Security, 2012, Deepening Democracy ... Op. Cit., hlm. 15. 
Dalam mewujudkan pemilu yang berintegritas, terdapat setidaknya 5 (lima) tantangan utama yaitu:16pertama, membangun negara hukum untuk menjamin Hak Asasi Manusia (HAM) dan keadilan pemilu. Kedua, membangun penyelenggara pemilu (Electoral Management Body) yang independen, profesional, dan kompeten sehingga dipercaya publik. Ketiga, menciptakan institusi dan norma multi-partai yang kompetitif dan pembagian kekuasaan yang mendukung demokrasi sebagai sistem jaminan keamanan bersama di antara pesaing politik. Keempat, menghilangkan hambatan hukum, politik, administratif, ekonomi, dan sosial untuk partisipasi politik yang universal dan setara. Kelima, mengatur keuangan politik yang tak terkontrol/tak terkendali, tak transparan, dan samar.

\section{Desain Institusional DKPP sebagai Pengawal Electoral Integrity}

Sebagaimana telah disinggung sebelumnya, Indonesia sebagai salah satu negara pada gelombang demokratisasi ketiga tidak hanya sedang megembangkan konsep pemilu berintegritas. Lebih jauh dari hal itu, Indonesia telah mewujudkannya dalam penyelenggaraan pemilu dengan membentuk DKPP yang bersifat permanen melalui UU Penyelenggara Pemilu. Sesuai dengan tujuannya untuk menjaga kemandirian, integritas, dan kredibilitas penyelenggara pemilu, kelahiran DKPP ini sekaligus menjadi salah satu bukti bahwa Indonesia telah berkomitmen untuk menerapkan electoral integrity.

Ide pembentukan lembaga ini didasarkan pada pentingnya penegakan etika bagi penyelenggara pemilu. Dalam melaksanakan tugas dan wewenangnya penyelenggara pemilu tidak hanya terikat pada rule of law, tetapi juga rule of ethics. Bangsa ini selain sedang menghadapi distorsi penegakan hukum, juga sedang mengalami goncangan nilai yang luar biasa. ${ }^{17}$ Oleh karena itu, penegakan etika tidak kalah pentingnya dengan penegakan hukum, apalagi di kalangan penyelenggara pemilu sebagai salah satu lembaga yang menentukan arah demokrasi bangsa.

Ide pembentukan lembaga tersebut mendapatkan legitimasi dari Mahkamah Konstitusi (MK) dalam putusannya Nomor 11/PUU-VIII/2010 yang

\footnotetext{
${ }^{16}$ Ibid., hlm. 6.

${ }^{17}$ Jimly Asshiddiqie, Dewan Kehormatan ... Loc. Cit.
} 
mengatakan:18 “...Bahkan, Dewan Kehormatan yang mengawasi perilaku penyelenggara Pemilu pun harus diartikan sebagai lembaga yang merupakan satu kesatuan fungsi penyelenggaraan pemilihan umum. Dengan demikian, jaminan kemandirian penyelenggara pemilu menjadi nyata dan jelas." Melalui pernyataan tersebut, MK menilai bahwa lembaga penegak etika penyelenggara pemilu juga harus diartikan sebagai lembaga yang melaksanakan fungsi penyelenggaraan pemilu. Oleh karena itu, sifat kelembagaannya harus tetap dan mandiri, tidak bersifat ad hoc dan tidak dapat diposisikan di bawah lembaga yang akan diawasi etika dan perilakunya sebagaimana DK KPU pada pemilu-pemilu sebelumnya.

Sebenarnya lembaga penegak kode etik penyelenggara pemilu bukan 'barang' baru di Indonesia. Sejak pemilu 2004 sampai dengan 2009 telah dikenal lembaga yang bernama Dewan Kehormatan KPU (DK KPU). Bahkan dalam pemilu 2009 dengan sifat kelembagaan yang ad hoc dan rekomendatif, DK KPU menuai prestasi yang cukup baik dengan mengungkap berbagai pelanggaran kode etik yang dilakukan oleh penyelenggara pemilu. Namun, pasca lahirnya putusan MK Nomor 11/PUU-VIII/2010 yang memberikan tafsir baru atas Pasal 22E ayat (5) UUD NRI 1945 yang kemudian diadopsi oleh UU 15/2011, DK KPU bertransformasi menjadi DKPP dengan posisi dan kedudukan yang lebih kuat. Transformasi tersebut didasari pada paradigma baru mengenai kelembagaan penyelenggara pemilu bahwa KPU, Bawaslu dan DKPP merupakan satu kesatuan fungsi penyelenggaraan pemilu, sehingga masing-masing lembaga harus bersifat tetap dan mandiri.

Dalam Pasal 109 ayat (1) UU Penyelenggara Pemilu dinyatakan DKPP bersifat tetap dan berkedudukan di ibu kota negara. Sedangkan fungsi dibentuknya DKPP sebagaimana dinyatakan dalam Pasal 109 ayat (2) UU Penyelenggara Pemilu adalah untuk memeriksa dan memutuskan pengaduan dan/atau laporan adanya dugaan pelanggaran kode etik yang dilakukan oleh anggota KPU, anggota KPU Provinsi, anggota KPU Kabupaten/Kota, anggota PPK, anggota PPS, anggota PPLN, anggota KPPS, anggota KPPSLN, anggota Bawaslu, anggota Bawaslu Provinsi dan anggota Panwaslu Kabupaten/Kota,

${ }^{18}$ Lihat putusan MK Nomor 11/ PUU-VIII/2010 tentang pengujian Undang-Undang Nomor 22 Tahun 2007 tentang Penyelenggara Pemilu, hlm. 111-112. 
anggota Panwaslu Kecamatan, anggota Pengawas Pemilu Lapangan dan anggota Pengawas Pemilu Luar Negeri.

Mengenai keanggotaan DKPP yang diatur dalam Pasal 109 ayat (4) UU Penyelenggara Pemilu sempat menuai kontroversi yang berujung pada judicial review pasal tersebut ke MK. Sebelum putusan MK, Pasal 109 ayat (4) UU Penyelenggara Pemilu mengatur keanggotaan DKPP terdiri dari: a) 1 (satu) orang unsur KPU; b) 1 (satu) orang unsur Bawaslu; c) 1 (satu) orang utusan masingmasing partai politik yang ada di DPR; d) 1 (satu) orang utusan Pemerintah; e) 4 (empat) orang tokoh masyarakat dalam hal jumlah utusan partai politik yang ada di DPR berjumlah ganjil atau 5 (lima) orang tokoh masyarakat dalam hal jumlah utusan partai politik yang ada di DPR berjumlah genap.

Utusan DPR dan Pemerintah sebagaimana diatur dalam huruf c, d dan e yang menjadi akar persoalan. Para pemohon uji materi menilai ketentuan huruf $\mathrm{c}$, $\mathrm{d}$ dan e tersebut merupakan bentuk nyata keinginan partai politik peserta pemilu terhadap pengamanan kepentingan dalam pemilu. Lebih lanjut, ketentuan tersebut juga membuka ruang intervensi yang begitu besar, padahal konstitusi telah mensyaratkan kelembagaan penyelenggara pemilu harus bersifat mandiri.

MK melalui putusannya Nomor 81/PUU-IX/2011 akhirnya mengabulkan permohonan pemohon dengan menyatakan Pasal 109 ayat (4) huruf c, huruf d, dan ayat (5) UU Penyelenggara Pemilu bertentangan dengan konstitusi. Selain itu juga menyatakan Pasal 109 ayat (4) huruf e UU Penyelenggara Pemilu sepanjang bagian kalimat "4 (empat) orang tokoh masyarakat dalam hal jumlah utusan partai politik yang ada di DPR berjumlah ganjil atau ... dalam hal jumlah utusan partai politik yang ada di DPR berjumlah genap" tidak mempunyai kekuatan hukum mengikat, sehingga Pasal 109 ayat (4) tersebut selengkapnya harus dibaca: “DKPP sebagaimana dimaksud pada ayat (1) terdiri dari: a) 1 (satu) orang unsur KPU; b) 1 (satu) orang unsur Bawaslu; c) 5 (lima) orang tokoh masyarakat. Dengan demikian anggota DKPP berjumlah 7 (tujuh) orang yang terdiri dari 1 (satu) orang unsur KPU, 1 (satu) orang unsur Bawaslu, dan 5 (lima) orang tokoh masyarakat.

Terkait dengan mekanisme rekrutmen anggota DKPP, UU Penyelenggara Pemilu belum mengatur secara lebih detail sebagaimana mekanisme rekrutmen 
anggota KPU dan Bawaslu. Untuk anggota DKPP yang berasal dari unsur KPU dan Bawaslu memang sudah jelas mengikuti mekanisme yang berlaku untuk rekrutmen anggota kedua lembaga tersebut. Namun, untuk anggota DKPP yang berasal dari unsur masyarakat, mekanisme rekrutmennya belum diatur dalam UU Penyelenggara Pemilu. Dalam Pasal 109 ayat (6) UU Penyelenggara Pemilu memang dinyatakan bahwa anggota DKPP yang berasal dari tokoh masyarakat diusulkan oleh Presiden sebanyak 2 (dua) orang dan oleh DPR sebanyak 3 (tiga) orang. Namun, mekanismenya belum diatur dalam UU tersebut, sehingga Presiden dan DPR dapat mengatur sendiri mekanismenya.

Mekanisme rekutmen anggota DKPP dari unsur masyarakat yang belum jelas tersebut menimbulkan persoalan dalam rekrutmen anggota DKPP periode 2012-2017. Presiden dan DPR tidak menerapkan open recruitment untuk mengisi jabatan anggota DKPP dari unsur masyarakat. Mekanisme yang cenderung tidak terbuka tersebut menuai kritik dari publik terutama para pegiat pemilu. Mekanisme yang demikian dikhawatirkan menghasilkan calon-calon yang telah terkooptasi oleh kepentingan kedua lembaga tinggi negara tersebut, selain kemandiriannya berpotensi terdistorsi. Oleh karena itu, ke depan memang perlu diatur secara lebih komprehensif dan detail terkait mekanisme rekutmen anggota DKPP dari unsur masyarakat yang diusulkan oleh Presiden dan DPR.

Adapun tugas DKPP sebagaimana disebutkan dalam Pasal 111 ayat (3) UU Penyelenggara Pemilu meliputi: a. menerima pengaduan dan/atau laporan dugaan adanya pelanggaran kode etik oleh Penyelenggara Pemilu; b. melakukan penyelidikan dan verifikasi, serta pemeriksaan atas pengaduan dan/atau laporan dugaan adanya pelanggaran kode etik oleh Penyelenggara Pemilu; c. menetapkan putusan; dan d. menyampaikan putusan kepada pihak-pihak terkait untuk ditindaklanjuti.

\section{Analisis Kritis Kewenangan DKPP dalam Memeriksa dan Memutus Dugaan Pelanggaran Kode Etik Penyelenggara Pemilu}

Kehadiran DKPP membawa khazanah baru dalam dinamika penyelenggaraan pemilu di Indonesia.Pemilu di Indonesia tidak lagi hanya 
berpedoman pada prinsip luber dan jurdil, tetapi juga mengedepankan aspek integritas dalam setiap penyelenggaraannya. Namun demikian, sepak terjang DKPP dalam melaksanakan tugas dan wewenangnya terkadang melampaui ketentuan yang telah diatur dalam peraturan perundang-undangan. Hal tersebut membuat posisinya 'seakan-akan' lebih tinggi dari KPU dan Bawaslu, karena selain dapat memberhentikan anggota dari kedua lembaga tersebut, DKPP ternyata seringkali memberikan perintah untuk melakukan atau tidak melakukan suatu yang sebenarnya menjadi otoritas penuh lembaga penyelenggara dan pengawas pemilu tersebut.

Dilihat dari peraturan perundang-undangan yang berlaku, DKPP dalam memeriksa dan memutus perkara melalui ketiga putusannya sebagaimana telah diuraikan sebelumnya, dapat dikatakan telah melampaui kewenangannya. Pertama, Putusan DKPP Nomor 73/DKPP-PKE-II/2013 secara implisit memerintahkan KPU untuk memasukkan kembali Selviana Sofyan Hosen sebagai pengadu ke dalam DCT. Hal tersebut dapat dilihat dalam pertimbangan DKPP sebagai berikut:

“... bahwa adalah kewajiban moral dan etis untuk untuk memulihkan hak Pengadu menjadi calon legislatif. Mengingat bahwa DKPP tidak dapat mengubah keputusan sidang sengketa Bawaslu yang bersifat final dan harus dihormati, dan sekaligus, dengan tetap berada dalam sikap yang demikian, DKPP dapat memaklumi dan menghormati apabila KPU memulihkan hak konstitusinal Pengadu dengan mengubah sendiri keputusannya sebagaimana mestinya. Iika perubahan dimaksud dilakukan KPU, DKPP menjamin bahwa hal tersebut tidak melanggar kode etik karena hak konstitusional Pengadu yang dipenuhi dengan manfaat dan keadilannya jauh lebih utama dibandingkan dengan kemuliaan prosedural yang bersifat formalistik."

Walaupun tidak secara eksplisit memerintahkan KPU untuk memulihkan hak konstitusional Selviana Sofyan Hosen dengan memasukkan kembali yang bersangkutan ke dalam DCT Dapil Sumatera Barat I, akan tetapi DKPP dalam pertimbangan putusannya di atas menyatakan KPU dijamin tidak melakukan pelanggaran kode etik hanya apabila mengubah keputusannya yang mencoret Selviana Sofyan Hosen dari DCT. Putusan DKPP ini semacam "jebakan" bagi KPU yang membuat akhirnya KPU tidak memiliki pilihan lain kecuali memasukkan kembali pengadu ke dalam DCT.

Tindakan DKPP tersebut tidak dibenarkan menurut peraturan prundangundangan yang berlaku. Penetapan DCT anggota DPR sebagaimana diatur dalam 
Pasal 66 UU pemilu merupakan wewenang KPU. Selain itu, dalam Pasal 8 ayat (1) huruf g UU Penyelenggara Pemilu juga ditegaskan bahwa penetapan peserta pemilu merupakan ranah kewenangan KPU. Berdasarkan hal tersebut, Perintah DKPP kepada KPU melalui putusannya untuk memasukkan kembali Selviana Sofyan Hosen ke dalam DCT tentu telah melampaui kewenangannya, karena penetapan dapat tidaknya seseorang menjadi peserta pemilu dan berhak dimasukkan ke dalam DCT merupakan kewenangan penuh KPU.

Kedua, Putusan DKPP Nomor 74/DKPP-PKE-II/213 secara eksplisit memerintahkan KPU Provinsi Jawa Timur untuk melakukan peninjauan kembali terhadap status kepesertaan Khofifah Indar Parawansa dalam pemilukada Jawa Timur juga telah melampaui kewenangannya. Hal tersebut tercantum dalam amar putusan DKPP poin kelima sebagai berikut: "Memerintahkan kepada Komisi Pemilihan Umum Republik Indonesia untuk melakukan peninjauan kembali secara cepat dan tepat terhadap Keputusan KPU Provinsi Jawa Timur sesuai maksud, prinsip dan etika penyelenggara pemilu dalam rangka pemulihan hak konstitusional Dra. Hj. Khofifah Indar Parawansa dan H. Herman Suryadi Sumawiredja."

Tindakan DKPP melalui putusannya di atas tentu tidak sesuai dengan kewenangan yang diberikan oleh UU. Sebagaimana diatur dalam Pasal 9 ayat (3) huruf g UU Penyelenggara Pemilu bahwa penetapan calon gubernur yang telah memenuhi persyaratan merupakan wewenang KPU Provinsi, bukan DKPP. Berdasarkan hal tersebut, seharusnya penetapan apakah Khofifah Indar Parawansa dapat menjadi peserta dalam pemilukada Jawa Timur atau tidak, diserahkan sepenuhnya kepada KPU Provinsi Jawa Timur. DKPP semestinya tidak mengambil alih hal tersebut, karena tentu akan melampaui kewenangannya.

Ketiga, Putusan DKPP Nomor 83 \& 84/DKPP-PKE-II/2013 secara eksplisit juga memerintahkan KPU Provinsi Banten untuk memulihkan dan mengembalikan hak konstitusional bakal pasangan calon Arief R WismansyahSachrudin dan bakal pasangan calon Ahmad Marju Kodri-Gatot Suprijanto untuk menjadi pasangan calon peserta pemilukada Kota Tangerang tahun 2013. Hal tersebut tercantum dalam amar putusan DKPP poin keempat sebagai berikut: 
“Memerintahkan kepada Komisi Pemilihan Umum Provinsi Banten untuk memulihkan dan mengembalikan hak konstitusional Bakal Pasangan Calon $\mathrm{H}$. Arief R. Wismansvah-H. Sachrudin dan Bakal Pasangan Calon H. Ahmad Mariu Kodri-Gatot Supriianto untuk meniadi Pasangan Calon Peserta Pemilukada Walikota dan Wakil Walikota Tangerang Tahun 2013 dengan tanpa merugikan Pasangan Calon Peserta Pemilukada Walikota dan Wakil Walikota Tahun 2013 lain yang telah ditetapkan sebelumnya."

Tindakan DKPP dalam putusan di atas juga telah melampaui kewenangannya. Sebagaimana diatur dalam Pasal 10 ayat (3) huruf i UU Penyelenggara bahwa penetapan calon bupati/walikota yang memenuhi persyaratan merupakan wewenang KPU Kabupaten/Kota.Berdasarkan hal tersebut, keputusan untuk mengembalikan atau tidak bakal pasangan calon untuk menjadi peserta dalam pemilukada Kota Tangerang di atas bukan merupakan kewenangan DKPP.

Fungsi dan Kewenangan DKPP telah diatur dalam UU Penyelenggara Pemilu. Dalam Pasal 109 ayat (2) UU Penyelenggara Pemilu secara tegas dinyakatan bahwa DKPP dibentuk untuk memeriksa dan memutuskan pengaduan dan/atau laporan adanya dugaan pelanggaran kode etik yang dilakukan oleh anggota KPU, anggota KPU Provinsi, anggota KPU Kabupaten/Kota, anggota PPK, anggota PPS, anggota PPLN, anggota KPPS, anggota KPPSLN, anggota Bawaslu, anggota Bawaslu Provinsi dan anggota Panwaslu Kabupaten/Kota, anggota Panwaslu Kecamatan, anggota Pengawas Pemilu Lapangan dan anggota Pengawas Pemilu Luar Negeri. Adapun wewenang DKPP diatur dalam Pasal 111 ayat (4) UU Penyelenggara Pemilu yang meliputi: a. memanggil Penyelenggara Pemilu yang diduga melakukan pelanggaran kode etik untuk memberikan penjelasan dan pembelaan; $b$. memanggil pelapor, saksi, dan/atau pihak-pihak lain yang terkait untuk dimintai keterangan, termasuk untuk dimintai dokumen atau bukti lain; dan c. memberikan sanksi kepada Penyelenggara Pemilu yang terbukti melanggar kode etik.

Pasal-pasal di atas menunjukkan bahwa UU Penyelenggara Pemilu sebenarnya telah mengatur batas-batas kewenangan DKPP. Berdasarkan ketentuan di atas, DKPP hanya berwenang untuk memeriksa dan memutus dugaan pelanggaran kode etik penyelenggara pemilu. Oleh karena itu, dalam 
putusannya, seharusnya DKPP hanya menentukan terbukti atau tidaknya dugaan pelanggaran kode etik yang diadukan oleh pengadu serta memuat sanksi bagi penyelenggara pemilu yang terbukti melakukan pelanggaran kode etik tersebut. DKPP tidak diberikan legitimasi oleh UU untuk ikut campur dalam ranah administrasi pemilu seperti yang terjadi dalam ketiga putusannya sebagaimana telah diuraikan di atas.

Harus diakui UU Penyelenggara Pemilu memang belum cukup komprehensif dalam mengatur wewenang DKPP. Namun, hal tersebut tidak dapat dijadikan justifikasi terhadap tindakan-tindakan DKPP yang melampaui wewenang yang telah diberikan oleh UU.Mengingat dalam hukum administrasi keabsahan tindakan pemerintahan diukur berdasarkan wewenang yang diatur dalam peraturan perundang-undangan. ${ }^{19}$ Dengan kata lain salah satu sumber wewenang adalah peraturan perundang-undangan. ${ }^{20}$ Selain itu, dalam hukum administrasi negara juga dikenal adanya pembatasan wewenang oleh tiga hal yaitu: isi/materi (materiae), wilayah/ruang (locus), dan waktu (tempus). Cacat dalam aspek-aspek tersebut menimbulkan cacat wewenang atau dalam artian bahwa di luar batas-batas itu suatu tindakan pemerintahan merupakan tindakan tanpa wewenang (onbevoegdheid). Tindakan tanpa wewenang dapat berupa:21 1 . Onbevoegdheid ratione materiae, apabila suatu keputusan tidak ada dasarnya dalam peraturan perundang-undangan atau dikeluarkan oleh pejabat yang tidak berwenang; 2. Onbevoegdheid ratione loci, keputusan yang diambil oleh pejabat yang berada di luar wilayahnya secara geografis; 3 . Onbevoegdheid ratione temporis, apabila keputusan dibuat oleh pejabat yang belum berwenang atau tidak berwenang lagi untuk mengeluarkan keputusan.

Berdasarkan teori kewenangan dalam hukum administrasi tersebut, tindakan DKPP yang memerintahkan KPU untuk melakukan sesuatu dalam ranah administrasi pemilu sebagaimana dalam tiga contoh kasus di atas, dapat dikualifikasikan sebagai tindakan tanpa wewenang (onbevoegdheid) khususnya hlm. 154 .

${ }^{19}$ S. F. Marbun, Peradilan Administrasi Negara dan Upaya Administrasi di Indonesia, Liberty, Yogyakarta, 1997,

20 Indroharto, Usaha Memahami Undang-Undang tentang Peradilan Tata Usaha Negara, Pustaka Harapan, Jakarta, 1993, hlm. 90

${ }^{21}$ Rusdianto, Teori Kewenangan (Theorie Van Bevoegdheid), Bahan Kuliah Magister Kenotariatan Universitas Narotama Surabaya tahun 2012. 
onbevoegdheid ratione materiae. Alasannya, tindakan dan keputusan yang diambil DKPP tersebut tidak didasarkan pada peraturan perundang-undangan yang berlaku, atau tidak memiliki pijakan yuridis. Bahkan tindakan yang dilakukan DKPP tersebut telah melanggar ketentuan peraturan perundang-undangan yang berlaku.

Tindakan DKPP dalam ketiga putusannya yang telah melampaui wewenang yang diberikan UU sebagaimana telah dijelaskan di atas tentunya bukan tanpa alasan. Jimly Asshiddiqie mengatakan, dalam memeriksa dan memutus pelanggaran kode etik, DKPP mengkui tidak hanya menggunakan paradigma keadilan retributif (retributive justice) yang mengutamakan sistem sanksi yang bersifat menghukum, membalas dendam, melampiaskan sakit hati, dan/atau menyalurkan kemarahan. Akan tetapi, DKPP juga menggunakan cara pandang keadilan restoratif (restorative justice). Dalam paradigma restorative justice, apabila seseorang terbukti melanggar hukum, yang penting mendapat perhatian justru adalah nasib korban yang harus dipulihkan. Dengan demikian DKPP tidak dapat 'menutup mata' ketika dalam suatu pelanggaran kode etik ditemukan pelanggaran terhadap hak-hak pengadu sebagai korban, maka hak-hak pengadu tersebut juga sudah seharusnya dipulihkan. ${ }^{22}$

Paradigma restorative justice yang diadopsi DKPP dalam memeriksa dan memutus dugaan pelanggaran kode etik memang sesuatu hal yang positif. Akan tetapi, penerapan paradigma tersebut juga tidak boleh mengesampingkan peraturan perundang-undangan yang berlaku. Hak-hak korban atas suatu pelanggaran kode etik yang dilakukan penyelenggara pemilu memang sudah seharusnya dipulihkan. Namun demikian, pemulihan atas hak-hak tersebut juga harus didasarkan pada ketentuan peraturan perundang-undangan. Sesuai dengan UU Penyelenggara Pemilu dan UU Pemilu, lembaga yang berwenang memulihkan dan mengembalikan hak-hak korban sebagai peserta pemilu atau pemilukada adalah KPU dan jajarannya, karena yang berwenang menetapkan peserta pemilu atau pemilukada adalah KPU dan jajarannya. Oleh karena itu, idealnya DKPP tidak dibenarkan lagi memberikan perintah kepada KPU untuk melakukan atau tidak melakukan sesuatu dalam ranah administrasi pemilu,

${ }^{22}$ Jimly Asshiddiqie, Pengenalan tentang DKPP... Op. Cit., hlm. 4-5. 
karena ranah administrasi pemilu merupakan kewenangan penuh KPU dan jajarannya.

Sebenarnya sikap "superioritas" DKPP dalam penyelenggaraan Pemilu juga turut disebabkan oleh sifat putusannya yang final dan mengikat sebagaimana diatur dalam Pasal 112 ayat (12) UU Penyelenggara Pemilu. Namun, melalui putusan Nomor 31/PUU-XI/2013, MK telah memberikan tafsir terhadap pasal tersebut. Dalam amar putusannya, MK menyatakan bahwa pasal tersebut harus dimaknai sebagai berikut: "Putusan sebagaimana dimaksud pada ayat (10) bersifat final dan mengikat bagi Presiden, KPU, KPU Provinsi, KPU Kabupaten/Kota, danBawaslu".

Tafsir di atas didasari oleh penilaian MK yang menganggap DKPP bukanlah pelaksana kekuasaan kehakiman. Dalam pertimbangan putusannya, MK menyatakan "DKPP tidak termasuk dalam pengadilan khusus yang masuk dalam salah satu lingkungan peradilan di bawah MA sebagaimana dimaksudkan oleh Pasal 24 ayat (2) UUD 1945 dan Pasal 27 ayat (1) UU 48/2009 serta tidak termasuk pula sebagai salah satu pelaku kekuasaan kehakiman sebagaimana dimaksud Pasal 24 ayat (2) UUD 1945."23 Lebih lanjut dalam pertimbangannya MK menyatakan:24

“....Putusan DKPP yang bersifat final dan mengikat sebagaimana dimaksud dalam Pasal 112 ayat (12) UU 15/2011 dapat menimbulkan ketidakpastian hukum apakah final dan mengikat yang dimaksud dalam Undang-Undang tersebut adalah sama dengan final dan mengikatnya putusan lembaga peradilan. Untuk menghindari ketidakpastian hukum atas adanya ketentuan tersebut, Mahkamah perlu menegaskan bahwa putusan final dan mengikat DKPP tidak dapat disamakan dengan putusan final dan mengikat dari lembaga peradilan pada umumnya oleh karena DKPP adalah perangkat internal penyelenggara Pemilu yang diberi wewenang oleh Undang-Undang. Sifat final dan mengikat dari putusan DKPP haruslah dimaknai final dan mengikat bagi Presiden, KPU, KPU Provinsi, KPU Kabupaten/Kota, maupun Bawaslu dalam melaksanakan putusan DKPP. Adapun keputusan Presiden, KPU, KPU Provinsi, KPU Kabupaten/Kota, maupun Bawaslu adalah merupakan keputusan pejabat TUN yang bersifat konkrit, individual, dan final yang dapat menjadi objek gugatan di peradilan TUN. Apakah peradilan TUN akan memeriksa dan menilai kembali putusan DKPP yang menjadi dasar keputusan Presiden, KPU, KPU Provinsi, KPU Kabupaten/Kota, maupun Bawaslu, hal tersebut adalah merupakan kewenangan peradilan TUN..."

Putusan MK di atas telah memperjelas sifat putusan DKPP yang sempat menjadi perdebatan. Berdasarkan putusan MK tersebut, diketahui bahwa sifat

${ }^{23}$ Lihat putusan Mahkamah Konstitusi Nomor31/PUU-XI/2013 tentang Pengujian Undang-Undang Nomor 15 Tahun 2011 tentang Penyelenggara Pemilihan, hlm. 70.

${ }^{24}$ Ibid., hlm. 72-73. 
final dan mengikatnya putusan DKPP tidak sama dengan sifat final dan mengikatnya suatu putusan pengadilan, karena DKPP bukanlah pelaku kekuasaan kehakiman melainkan perangkat internal penyelenggara Pemilu, sehingga putusan DKPP hanya mengikat bagi lembaga atau institusi yang berwenang menindaklanjuti putusan DKPP itu.

\section{Pola Hubungan antara KPU, Bawaslu, dan DKPP Berbasis Electoral Integrity}

Salah satu tantangan dalam mewujudkan pemilu berintegritas (electoral integrity) sebagaimana tercantum dalam laporan kerja Global Commision on Election, Democracy and Security adalah membangun penyelenggara pemilu (Electoral Management Body) yang independen, profesional, dan kompeten sehingga dipercaya publik. ${ }^{25}$ Untuk mewujudkan penyelenggara pemilu yang independen, profesional, dan kompeten tersebut, seluruh penyelenggara pemilu dan jajarannya harus tunduk dan patuh pada nilai-nilai moral dan etika dalam seluruh siklus pemilu (electoral circle). ${ }^{26}$

Di Indonesia, pasca lahirnya UU 15 Tahun 2011 tentang Penyelenggara Pemilu terdapat 3 (tiga) lembaga yang menjalankan fungsi penyelenggaraan pemilu yaitu KPU, Bawaslu dan DKPP. Secara garis besar pola hubungan ketiga lembaga itu dapat dijelaskan sebagai berikut; KPU berfungsi sebagai penyelenggara seluruh tahapan-tahapan pemilu. Penyelenggaraan tahapantahapan tersebut diawasi oleh Bawaslu. Sedangkan DKPP berfungsi sebagai penegak etika penyelenggara pemilu, baik KPU dan jajarannya maupun Bawaslu dan jajarannya. Dalam UU Penyelenggara Pemilu dan UU Pemilu diatur lebih lanjut mengenai tugas dan wewenang masing-masing lembaga.

Dalam Pasal 8 ayat (1) UU Penyelenggara pemilu ditegaskan bahwa, tugas dan wewenang KPU dalam penyelenggaraan Pemilu anggota Dewan Perwakilan Rakyat, Dewan Perwakilan Daerah, dan Dewan Perwakilan Rakyat Daerah meliputi: a. merencanakan program dan anggaran serta menetapkan jadwal; b. menyusun dan menetapkan tata kerja KPU, KPU Provinsi, KPU Kabupaten/Kota, PPK, PPS, KPPS, PPLN, dan KPPSLN; c. menyusun dan menetapkan pedoman teknis untuk setiap

\footnotetext{
${ }^{25}$ Global Commision on Election, Democracy and Security, Deepening Democracy ... Loc., Cit.

${ }^{26}$ Ibid.
} 
tahapan Pemilu setelah terlebih dahulu berkonsultasi dengan DPR dan Pemerintah; d. mengoordinasikan, menyelenggarakan, dan mengendalikan semua tahapan Pemilu; e. menerima daftar pemilih dari KPU Provinsi; f. memutakhirkan data pemilih berdasarkan data kependudukan yang disiapkan dan diserahkan oleh Pemerintah dengan memperhatikan data Pemilu dan/atau pemilihan gubernur, bupati, dan walikota terakhir dan menetapkannya sebagai daftar pemilih; g. menetapkan peserta Pemilu; h. menetapkan dan mengumumkan hasil rekapitulasi penghitungan suara tingkat nasional berdasarkan hasil rekapitulasi penghitungan suara di KPU Provinsi untuk Pemilu Anggota Dewan Perwakilan Rakyat dan hasil rekapitulasi penghitungan suara di setiap KPU Provinsi untuk Pemilu Anggota Dewan Perwakilan Daerah dengan membuat berita acara penghitungan suara dan sertifikat hasil penghitungan suara; i. membuat berita acara penghitungan suara dan sertifikat penghitungan suara serta wajib menyerahkannya kepada saksi peserta Pemilu dan Bawaslu; j. menerbitkan keputusan KPU untuk mengesahkan hasil Pemilu dan mengumumkannya; k. menetapkan dan mengumumkan perolehan jumlah kursi anggota Dewan Perwakilan Rakyat, Dewan Perwakilan Rakyat Daerah Provinsi, dan Dewan Perwakilan Rakyat Daerah Kabupaten/Kota untuk setiap partai politik peserta Pemilu anggota Dewan Perwakilan Rakyat, dan Dewan Perwakilan Rakyat Daerah; 1. mengumumkan calon anggota Dewan Perwakilan Rakyat dan Dewan Perwakilan Daerah terpilih dan membuat berita acaranya; m. menetapkan standar serta kebutuhan pengadaan dan pendistribusian perlengkapan; n. menindaklanjuti dengan segera rekomendasi Bawaslu atas temuan dan laporan adanya dugaan pelanggaran Pemilu; o. mengenakan sanksi administratif dan/atau menonaktifkan sementara anggota KPU Provinsi, anggota PPLN, anggota KPPSLN, Sekretaris Jenderal KPU, dan pegawai Sekretariat Jenderal KPU yang terbukti melakukan tindakan yang mengakibatkan terganggunya tahapan penyelenggaraan Pemilu yang sedang berlangsung berdasarkan rekomendasi Bawaslu dan/atau ketentuan peraturan perundang-undangan; p. melaksanakan sosialisasi penyelenggaraan Pemilu dan/atau yang berkaitan dengan tugas dan wewenang KPU kepada masyarakat; q. menetapkan kantor akuntan publik untuk mengaudit dana kampanye dan mengumumkan laporan sumbangan dana kampanye; r. melakukan evaluasi dan membuat laporan setiap tahapan 
penyelenggaraan Pemilu; dan s. melaksanakan tugas dan wewenang lain sesuai ketentuan peraturan perundang-undangan.

Hal yang kurang lebih sama juga dilakukan oleh KPU untuk menyelenggarakan Pemilihan Presiden dan Wakil Presiden serta pemilihan Kepala Daerah.

Sementara wewenang Bawaslu diatur dalam Pasal 73 ayat (3) UU Penyelenggara Pemilu sebagai berikut: a. menerima laporan dugaan pelanggaran terhadap pelaksanaan ketentuan peraturan perundang-undangan mengenai Pemilu; b. menerima laporan adanya dugaan pelanggaran administrasi Pemilu dan mengkaji laporan dan temuan, serta merekomendasikannya kepada yang berwenang; c. menyelesaikan sengketa Pemilu; d. membentuk Bawaslu Provinsi; e. mengangkat dan memberhentikan anggota Bawaslu Provinsi; dan f. melaksanakan wewenang lain yang diatur dalam ketentuan peraturan perundang-undangan.

Selain itu, UU Penyelenggara Pemilu juga memberikan kewenangan kepada Bawaslu untuk menyelesaikan sengketa pemilu. UU Pemilu juga menjabarkan lebih lanjut mengenai sengketa pemilu dimaksud. Dalam Pasal 257 UU Pemilu sengketa pemilu didefinisikan sebagai sengketa yang terjadi antarpeserta pemilu dan sengketa Peserta Pemilu dengan penyelenggara pemilu sebagai akibat dikeluarkannya keputusan KPU, KPU Provinsi, dan KPU Kabupaten/Kota.

Adapun DKPP sebagaimana juga telah dijelaskan pada pembahasan sebelumnya berwenang memeriksa dan memutuskan pengaduan dan/atau laporan adanya dugaan pelanggaran kode etik yang dilakukan oleh seluruh penyelenggara pemilu baik KPU dan jajarannya maupun Bawaslu dan jajarannya. DKPP lah lembaga yang memastikan seluruh penyelenggara pemilu bekerja tidak hanya atas dasar peraturan perundang-undangan, akan tetapi juga atas dasar nilai-nilai moral dan etika.

Dengan desain pola hubungan sebagaimana digambarkan di atas, pola hubungan antar penyelenggara pemilu di Indonesia dapat dikatakan telah mengadopsi electoral integrity. Sebagaimana disebutkan sebelumnya, salah satu indikator pemilu berintegritas adalah kepatuhan pada nilai-nilai moral dan etika dalam seluruh siklus pemilu. Di Indonesia, hal tersebut telah diwujudkan dengan 
lahirnya DKPP yang diikuti dengan pembentukan Peraturan Bersama Komisi Pemilihan Umum, Badan Pengawas Pemilihan Umum, Dewan Kehormatan Penyelenggara Pemilihan Umum Nomor 13 Tahun 2012, Nomor 11 Tahun 2012, Nomor 1 Tahun 2012 tentang Kode Etik Penyelenggara Pemilihan Umum (selanjutnya disebut Peraturan Bersama Kode Etik). Dalam peraturan bersama kode etik dirumuskan 12 (dua belas) asas yang menjadi pedoman bagi Penyelenggara Pemilu yaitu: a. mandiri; b. jujur; c. adil; d. kepastian hukum; e. tertib; f. kepentingan umum; g. keterbukaan; h. proporsionalitas; i. profesionalitas; j. akuntabilitas; k. efisiensi; dan 1. efektivitas. Asas-asas tersebut merupakan bagian dari nilai moral dan etika yang harus dipegang teguh penyelenggara pemilu demi mewujudkan pemilu berintegritas.

Namun yang menjadi catatan adalah untuk benar-benar mewujudkan pemilu berintegritas, masing-masing lembaga harus konsisten dalam menjalankan kewenangannya. Satu catatan khusus bagi DKPP, akan lebih baik apabila dalam menjalankan wewenangnya tidak sampai overlapping masuk ke ranah wewenang lembaga lain. Sebagai lembaga penegak etika seharusnya DKPP yang terdepan dan menjadi role model bagi lembaga-lembaga lainnya dalam menghidupkan dan mengimplementasikan nilai-nilai moral dan etika. Overlapping kewenangan merupakan salah satu bentuk ketidakprofesionalan, dan ketidakprofesionalan merupakan salah satu bentuk pelanggaran terhadap etika. Dengan demikian ke depan DKPP diharapkan lebih berhati-hati dalam melaksanakan tugas dan wewenangnya.

\section{Penutup}

Berdasarkan paparan di atas dapat disimpulkan bahwa batasan kewenangan DKPP telah diatur dalam UU Penyelenggara Pemilu. DKPP hanya berwenang memeriksa dan memutus dugaan pelanggaran kode etik yang dilakukan oleh penyelenggara pemilu. Selain itu, pola hubungan antar penyelenggara pemilu di Indonesia sebenarnya telah mengadopsi prinsip electoral integrity, namun terdapat catatan khusus bagi DKPP, yaitu akan lebih baik apabila dalam menjalankan wewenangnya tidak sampai overlapping masuk ke ranah wewenang lembaga lain, 
sebab overlapping kewenangan merupakan salah satu bentuk ketidakprofesionalan, dan ketidakprofesionalan merupakan salah satu bentuk pelanggaran etika.

Sebagai lembaga penegak etika seharusnya DKPP yang terdepan dan menjadi role model bagi lembaga-lembaga lainnya dalam menghidupkan dan mengimplementasikan nilai-nilai moral dan etika.

\section{Daftar Pustaka}

Asshiddiqie, Jimly, Pengenalan tentang DKPP untuk Penegak Hukum, Makalah yang disampaikan dalam Forum Rapat Pimpinan Kepolisian Republik Indonesia di Jakarta pada Februari 2013.

-------, Menegakkan Etika Penyeleggara Pemilu, Jakarta, PT. Raja Grafindo Persada, 2013.

Dewan Kehormatan Penyelenggara Pemilu: Mengawal Kehormatan Pemilu, makalah yang disampaikan dalam kegiatan Sosialisasi Dewan Kehormatan Penyelenggara Pemilihan Umum Republik Indonesia dengan jajaran Pemerintahan Provinsi Aceh, LSM, Ormas, OKP, Parpol, Media Massa dan Akademisi, di Aula Kantor Gubernur Aceh pada Jumat 21 Juni 2013 dan Sabtu 22 Juni 2013 di Ballrom Rektorat UNSIYAH Aceh.

Bari Azed, Abdul dan Makmur Amir, Pemilu dan Partai Politik di Indonesia, PSHTN FH UI, Jakarta, 2005.

Gostick, Adrian dan Dana Telford, Keunggulan Integritas, Terj, PT Bhuana Ilmu Populer, Jakarta, 2006.

Global Commision on Election, Democracy and Security, Deepening Democracy: A Strategy for Improving the Integrity of Elections Worldwide, Kofi Annan Foundation in Cooperation with International Institute for Democracy and Electoral Assistance (IDEA), Geneva, 2012.

Indroharto, Usaha Memahami Undang-Undang tentang Peradilan Tata Usaha Negara, Pustaka Harapan, Jakarta, 1993.

Marbun, S. F., Peradilan Administrasi Negara dan Upaya Administrasi di Indonesia, Yogyakarta, Liberty, 1997.

Rusdianto, Teori Kewenangan (Theorie Van Bevoegdheid), Bahan Kuliah Magister Kenotariatan Universitas Narotama Surabaya tahun 2012.

S. Goodwin-Gill, Guy, Free and Fair Elections: International Law and Practice, InterParliamentary Union, Geneva, 1994.

Republik Indonesia, Undang-Undang Dasar Negara Republik Indonesia Tahun 1945. 
Republik Indonesia, Undang-Undang Nomor 15 Tahun 2011 tentang Penyelenggara Pemilihan Umum.

Republik Indonesia, Undang-Undang Nomor 8 Tahun 2012 tentang Pemilihan Umum Anggota Dewan Perwakilan Rakyat, Dewan Perwakilan Daerah, dan Dewan Perwakilan Rakyat Daerah.

Peraturan Bersama Komisi Pemilihan Umum, Badan Pengawas Pemilihan Umum, Dewan Kehormatan Penyelenggara Pemilihan Umum Nomor 13 Tahun 2012, Nomor 11 Tahun 2012, Nomor 1 Tahun 2012 tentang Kode Etik Penyelenggara Pemilihan Umum.

Putusan Mahkamah Konstitusi Nomor 11/ PUU-VIII/2010 tentang pengujian Undang-Undang Nomor 22 Tahun 2007 tentang Penyelenggara Pemilu.

Putusan Mahkamah Konstitusi Nomor 31/PUU-XI/2013 tentang Pengujian Undang-Undang Nomor 15 Tahun 2011 tentang Penyelenggara Pemilihan Umum.

Putusan DKPP Nomor 73/DKPP-PKE-II/2013.

Putusan DKPP Nomor 74/DKPP-PKE-II/2013.

Putusan DKPP Nomor 83 \& 84/DKPP-PKE-II/2013. 